\title{
Patenting Activity - A Proxy of the Technology Gap? The Case of Korea and China
}

\section{Junghee Han ${ }^{1 *}$ and Wangwoo Lee ${ }^{2}$}

${ }^{1}$ Department of Management of Technology Program, Graduate School of Smart City Science Management Hongik University, Sejong-ro Sejong City, Korea ${ }^{2}$ KMA Consultants Inc., South Korea

\begin{abstract}
Technology is a key factor shaping economic growth. The technology gap between countries can be seen as a consequence of the disparity between patent protection levels and patenting activity. Technological progress depends on both domestic and foreign stocks of knowledge, the national infrastructure and the social institutional system. This paper discusses the extent to which the technology gap may be narrowed by strong levels of patent protection. The underlying premise to be assumed throughout is that patent rights have the power to influence the creation and diffusion of technology. As the importance of appropriability under many legal system increases, having a coherent strategy concerning intellectual property rights is crucial, both at the business and national levels. By considering data pertaining to patents, patenting activities, and social infrastructure, gathered from a number of sources, including IMD, World Bank, WIPO, and the Korean and Chinese national archives, this paper will focus on exploring the possibility that patents or patenting activities could serve as indicators forecasting the rate of adoption of new technologies within a country, whilst at the same time acknowledging some of their limitations in functioning as a proxy of the technology gap between countries.
\end{abstract}

Keywords: Intellectual property right; Technology gap; Knowledge spillover; Korea; China

\section{Introduction}

Technological development is characterized by a number of different facets including uncertainty, path dependency, cumulative nature, irreversibilites, tacitness, and inappropriabilty. In terms of particular branches of technology, each sector also takes on specific characteristics of the overriding technological regime. It is thus impossible to identify each individual process of innovation in technology. Fortunately, there appears to be a consensus over the types of new technology or knowledge that fall within the exclusive domain of authority for inventors. In general, technological advances are designed to enhance the capabilities of people and expand human possibilities. They change the world in ways that can have positive and/or negative impacts on the social and natural world. In many cases, IP law that increases appropriability for innovators has the potential to encourage technological innovation. In the long run, intellectual property law, including patent law, improves social utilities. Even though clearly inadequate as a standalone measure, patents could serve as a proxy of the national technological level. Patenting activity is an important channel for the flow and diffusion of knowledge, as inventors publicly disclose technical information in exchange for patent protection.

In line with this, the purpose of the patent system in each country, as it relates to intellectual property rights, is to accelerate the development of technology though the protection, encouragement, promotion, and utilization of inventions, thereby contributing to the development of the industry. The publication of inventions leads to the accumulation and utilization of technology and the advancement of industry. Granting exclusive rights for the commercial usage of a patented invention promotes commercialization, encourages the development of inventions, and leads to the advancement of industry.

In terms of the conditions that should be fulfilled for the acquisition of patent rights, a patent should have industrial utilization and applicability; it must be usable in industry. The technology must be novel as evaluated against prior art; it must not be known to the public before an application is submitted. Also, the new technology must involve at least one inventive step, and it must not be easily derivable from prior art, even though it differs from it.

The term of a patent right commences when the establishment of patent right is registered; it ends 20 years after the filing date of the patent application. The corresponding term for a utility model is 10 years. The effect of a patent right is subject to the principle of territoriality; that is, it is valid only in the country where the right is obtained.

Intellectual property law affords inventors, artists, and institutions certain exclusive rights to produce, copy, distribute, and license goods and technologies within a country. In principle, when a country strengthens its IPR protection this could facilitate the introduction of new products, information, and creative activities.

Recently, the technology gap between Korea and China has gradually been narrowing. This has been the subject of much heated debate in Korea, where it is considered unthinkable that Chinese manufacturers might be catching up, particularly in the case of information and communication technology (ICT). According to the government's statistics, the technology gap between Korea and China narrowed down significantly from -2.4 in 2013 to -1.8 in 2014 .

This paper focuses on the question of whether the utilization of intellectual property rights could be a proxy of the technology gap that exists between countries. The interrelationships between intellectual

*Corresponding author: Junghee Han, Professor of Management of Technology Program, Graduate School of Smart City Science Management Hongik University, Sejong-ro Sejong City, Korea, Tel: ++82-(0)10-5430-5049; E-mail: hjh0037@hongik.ac.kr

Received May 25, 2016; Accepted June 20, 2016; Published June 28, 2016

Citation: Han J, Lee W (2016) Patenting Activity - A Proxy of the Technology Gap? The Case of Korea and China. Intel Prop Rights. 4: 151. doi:10.4172/23754516.1000151

Copyright: (C) 2016 Han J, et al. This is an open-access article distributed under the terms of the Creative Commons Attribution License, which permits unrestricted use, distribution, and reproduction in any medium, provided the original author and source are credited. 
property (patents) and the technological gap will be further explored by examination of numerical data released by the IMD (Institute for Management Development), the WIPO (World Intellectual Property Office) and the World Bank, as well as domestic data from China and Korea.

\section{Some Remarks on Korean and Chinese Patent Law}

Even though there is evidence for the effectiveness of the patent in yielding high returns in the area of innovation, the recent data obtainable from market competitions is mixed [1]. The growth in patenting has renewed scholars' interest in evaluating the effectiveness of the patent system in promoting innovative activity. This paper begins with a review of the patent system and an outline of the history of the two countries under consideration, China and Korea.

This history of modern patent law in China is relatively short, since the current patent law was only first enacted in 1985, with two amendments following in 1992 and 2000. After the founding of the People's Republic of China, under a rigid plan economy system, a patent law had previously been enacted in 1950 by the Central People's Government, but this was not promulgated in the necessary way. In 2006, under the 'open-door legislation' policy, the State Intellectual Property Office sent a special delegation to Japan and the United States of America for research purposes. Later, the State Intellectual Property Office summed up and generalized the feedback opinions from respective circles, modified and perfected the draft and served the 'Draft for Comments' to the State Council on December 27 of the same year. Following this, Premier Wen Jabao, in 2008, deliberated and approved the Draft for comments under Chinese Patent Law.

However, after a compendium of the National Intellectual Property Strategy was released by the State Council on June 5, 2008 the implementation of the national intellectual property strategy was formally launched. The compendium was to set the basis for the proposed revision of China's intellectual law, including its patent law. The 'Draft for Comments' consisted of 82 Articles, divided into 8 chapters. According to current patent law in China, as well as that in most countries, any invention to which patent rights are to be granted must possess novelty, innovation, at least in some steps, and practical applicability. Under Article 23 of the Patent Law of China, any design to which patent rights are to be granted must not be identical with or similar to any design which before the date of filling has been publicly disclosed in the publications of the issuing country or abroad. In the legal literature, worldwide novelty is usually described as 'absolute novelty', and domestic novelty as 'relative novelty'.

In 1908, an imperial patent for command (Edict No. 196) was regarded as the initial version of Korean patent law. However, the imperial order became invalid after the colonization of Korea by Japan in 1910. After being freed from Japan's mandatory rule, the Patent Act was enacted under the military government (US Military Government Decree No. 91), supported by the United States. Thus, in 1946, the Patent Institute was established and patent laws were enacted. The 1946 Patent Act consisted of 16 chapters and 265 articles, and subsumed both the Utility Model Act and the Design Act. Under this act, the terms of a patent right would take effect when the establishment of the patent right had been registered; following U.S. patent law, they would expire after 17 years.

While the 1946 Patent Act was enacted under the influence of the United States, the 1961 Patent Act was the first patent law to be enacted directly under the sovereignty of the South Korea national government.
It contained only the Patent Act; the Design Act and Utility Model Act present in the 1946 Act were removed. It can be assumed that the purpose of the Patent Act of 1961 was to prevent abuse of patent rights in the context of the prevailing atmosphere at the time, which was, arguably, unfavorable for the development of new inventions. Article 4 of the Patent Act of 1961 stipulated the information relevant to that time and purpose. It legislated against the conferral of patent rights to an invention connected to food, water, chemical methods, or medicine. By taking into account the situation of the people, lacking food, water and hygiene as they were, the Patent Act of 1961 was intended to restrict inventors from owning exclusive rights to inventions, so that their inventions would serve the public interest. The Patent Act of 1961 tried to limit the scope of patent rights as much as possible for the sake of ordinary people. Interestingly, in order to protect domestic industries, the Patent Act of 1961 did not allow the conferral of patent rights for inventions of new medicines and chemical materials.

Article 45 of the Patent Act of 1961 did provide, however, for nonexclusive licenses for third parties in cases where the invention had lain dormant for more than 3 years, in the absence of mitigating factors. In view of this, it can be argued that, despite the almost complete lack of operation of mandatory, non-exclusive licenses, the Patent Act of 1961 was actually intended to promote and protect the domestic infant industry.

The globalization of the patent system was required in order to facilitate the invention of domestic technology. In response to the need to keep in step with the globalization of the times Korea joined the World Intellectual Property Organization Treaty (WIPO) in 1979) and the Paris Convention in 1980.

\section{Technology and Technology Gap Theory}

Since Schumpeter noted that economic growth is one of the processes at the forefront of technological innovation and implementation, 'catching-up', or narrowing the technology gap, has become a central area of interest for scholars. The technology gap approach, a model which explains the growth differences between countries, appeared in the 1960s. The concept of the technology gap model focused directly on two opposing forces- technology innovation, and imitation. The former tends to widen the technology gap, whilst the latter tends to narrow it [2-8]. This model can be classified as an endogenous theory of growth in that it is technology-related variables (such as investment in R\&D, and the number of patents awarded) that influence the growth rate.

Research on the technology gap has examined the variables governing economic growth; studies by Gerschenkron and Abramovize have shown that the capability to acquire knowledge from abroad is a key factor in explaining growth rate differentials over time $[2,3]$. A new perspective on technology as the driving force of growth and development has been taken by growth theory [6,9]. This theory recognizes first the importance of technology as an economic growth factor, and then the importance of the accumulation of technology at the corporate and national levels. Technology gap theory assesses the potential of a country to catch up (or close the technology gap) with respect to two main dimensions. The first of these is the country's technological absorptive capability (i.e., its ability to acquire technology from developed countries). The second is its innovative capabilities, in other words, the extent to which the country is able to generate new knowledge.

Historically, South Korea and China, as developing countries, have 
endeavored to close the technology gap. It is not easy to measure or estimate the technological state of a country. Many countries have been implementing a 'catch-up strategy' by imitating and using the technologies developed in more advanced countries. Utilization of knowledge and technologies from advanced countries is therefore a crucial and complementary growth engine that needs to be taken into account. Numerous prior studies with regard to the technology-gap theory have dealt with cost activity relating to investment in indigenous capabilities, capital equipment, infrastructure, etc. [7,4]. Without a sufficient level of such investments, a country is unlikely to rise out of its backwardness, and risks falling behind relative to the technology leaders, rather than 'catching up' [7]. Fagerberg assertion has been known as the 'technology gap theory' of economic growth [4].

According to Fagerberg, there are four assumptions underlying the technology gap theory. Firstly, there is a close relation between a country's economic and technological levels of development [5]. Secondly, the rate of economic growth of a country is positively influenced by the rate of growth in the technological sector of that country. Thirdly, it is possible for a country facing a technological gap, i.e., a country on a lower technological level than the countries on "the world innovation frontier", to increase its rate of economic growth through imitation ("catching up"). Fourthly, the rate at which a country exploits the possibilities offered by the technological gap depends on its ability to mobilize resources for transforming social, institutional and economic structures. Faberberg uses patents registered abroad as a proxy of innovation, and GDP per capita and total volume of R\&D as a proxy of imitation [5]. As mentioned above, there is a positive correlation between imitation potential measured in terms of GDP per capita and innovation capabilities. In other words, the technology gap approach postulates a positive correlation between innovation and imitation. Fagerberg notes that innovation; diffusion potential and other complementary factors also influence the economic growth [5]. The importance of innovation, as measured by the number of patents registered per year, appears to increase over time. In addition, this phenomenon has an important role to play in the growth of the economy in each country, in that the level of technological innovation of a country may depend on the patents and patenting activities within that country.

Differences in innovation, as measured by growth in the number of patents registered, explains relatively little initially, but emerges as a very powerful predictor of a country's ability to close the technology gap. From the findings of Fagerberg empirical study, patents were important in stimulating national economic growth through their role in fostering innovation [5].

On a national level, one of the factors that may lead to the formation of a technology gap is the diffusion process. It is the analysis of this diffusion process that is most interesting, both from an economic point of view and from within the field of innovation studies itself. Over time, technological knowledge spills over from both the corporate and national levels. Imitation tends to narrow gaps in technological competencies whereas innovation (i.e. the development of new technology) tends to widen these gaps, both at the corporate and national levels [10]. It was the country's diffusion of knowledge, the 'knowledge spillover', which led to the creation of the technology gap.

Relatively little is known about the nature and degree of the flow of knowledge between countries or regions. However, growth rates will be faster as knowledge stock increases [11]. Grossman and Helpman explain knowledge flow both in terms of a knowledge stock, and as a process of upgrading [11]. The knowledge stock determines national productivity in inventing new products and is a reflection of both domestic and foreign experience; the process of upgrading is built on the past research output across all countries.

Castellacci paper brings important insights to technology-gap theory. He argues that it is differences in the technological absorption capability of each country that bring about differences in the growth rate for these countries [8]. According to Castellacci, economic growth may be seen as the outcome arising from the interaction of three types of factors: innovation activities, diffusion (the potential for exploiting technologies developed elsewhere), and complementary and structural factors, which affect to what extent this potential is realized [8]. $\mathrm{He}$ argued that in the case of developed countries, ('first movers') the only source of growth for technology is the internal creation of innovation outputs, while for developing countries ('followers'), there is in addition the potential for an alternative growth engine, diffusion, the actual exploitation of which will depend on various structural and institutional factors relating to social capability (Figure 1).

Figure 1 illustrates that in the initial state 'a', the technology gap between the two countries is significant, but that it is likely to narrow over time, until at place ' $e$ ' there is no gap, due to the improvement of absorption capability, and change of complementary, structural and institutional factors in the Follower. After point ' $e$ ', it could even be possible for the Follower to surpass the First Mover according to the Follower's capabilities in such areas as technological absorption, innovation and adaptability of social institutions.

In particular, Blazsek and Escribano have analyzed interaction (spillovers) between patent innovation leaders and followers by using patents taken from Research and Development (R\&D) activities (i.e. scientific disclosure) [12]. They also note positive spillover effects from patent innovation leaders to followers. These positive spillover effects from the innovation leader to followers suggest that firms are competing "neck-and-neck" in terms of their innovation activity. Figure 2 shows that knowledge spillovers are also governed by laws; when the gap is high the learning capability is low, and therefore the knowledge spillovers are also low (this would be the case when the follower country is not able to exploit the potential spillovers by imitating the leader); on the other hand, when the gap becomes smaller, learning capability increases, and knowledge spillovers thus increase (this would be the case when the follower is able to exploit its backwardness) (Figure 2).

Summing up, from the above review of the 'technology gap theory', it has been claimed that the successful adoption of new technology is a costly activity that requires investment in such things as indigenous capabilities, capital equipment, social structural factors and infrastructure $[4,5,8]$

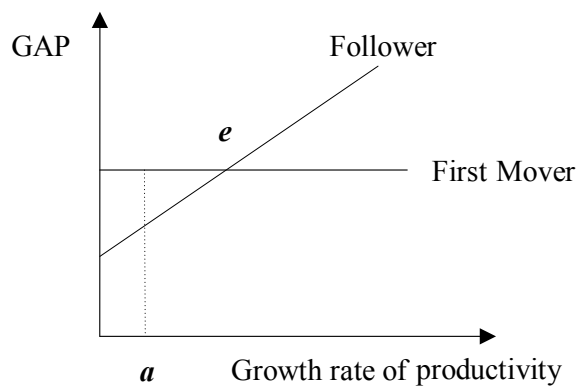

Figure 1: Adapted from Castellaci's technology gap and catching up model (2001). 
Citation: Han J, Lee W (2016) Patenting Activity - A Proxy of the Technology Gap? The Case of Korea and China. Intel Prop Rights. 4: 151. doi:10.4172/2375-4516.1000151

Page 4 of 8

\section{Scientific Infrastructure: An Overview of Patent and Patenting Activities in the Two Countries}

Geographically, Korea and China are neighbor countries. They also share many things in common, not only historically but also culturally. In recent years, China's economy has been skyrocketing. The average annual GDP growth rate was more than 9\% during the period 19922001 [13].

The bilateral trade volume has expanded rapidly since the start of diplomatic relations in 1992. China is Korea's number one trade partner, while Korea is number four on China's list with regards to trade volume. In 2015, in terms of the nominal global GDP level, Korea and China attained levels of $1.9 \%$ and $12.5 \%$ respectively. The two countries are gradually becoming more and more important for each other, both in terms of trade volume as well as in terms of their relationship, which is founded on a mutually-complementary perspective (Table 1). (2015).

Adapted from National trade organizations of China and Korea

Since the Korea-China free trade agreement (FTA) was concluded in 2014 , the bilateral economic trade level rose to new levels. The two countries agreed on a trade volume of 3,000 hundred million US dollars in 2015. Even though the world competitiveness ranking is not, in itself, a standalone measure of the total competitiveness of a country, it nonetheless gives a clear indication that China is one of the most

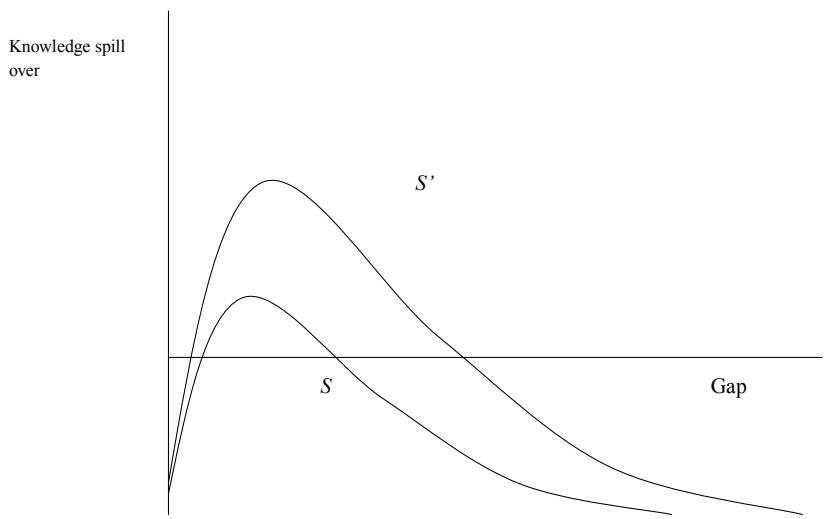

Figure 2: Knowledge spill over (Verspagen, 1997). promising countries in that regard. According to a report concerning world Competitiveness published by the IMD (International Institute for Management Development) in 2015, China is ranked $22^{\text {nd }}$ out of 61 countries while Korea is ranked $25^{\text {th }}[14]$.

When it comes to assessing the scientific infrastructure of a country, key factors include both total expenditure on $\mathrm{R} \& \mathrm{D}$ and the number of patent applications per capita (Table 2).

Author's modified data from IMD world competitiveness year book $(2013,2014)$.

In the case of total expenditure on $\mathrm{R} \& \mathrm{D}$ and scientific articles published by original authors, China ranks third and second respectively out of 61 countries. These variables could act as proxies of the rate of adoption of new technology, given that the degree of scientific infrastructure can be seen as a fairly reliable indicator of the development or creation of new technology in the future. Interestingly, China is far more relaxed than Korea in terms of its enforcement of IP property rights. As mentioned above, the degree of intensity of intellectual property rights has been correlated with the degree of diffusion of technology.

In general patent law tends to reflect the domestic industrial circumstances. For instance, in the case of Korea's patent law of 1946, new inventions (i.e., material, food, chemical clothing, etc.) were not covered by law in order to facilitate the people's welfare. At that time, Korea was being governed by the military government of the United States. Because Korea had just been liberated from Japan's colonial rule, essential items for living were in high demand, and the government had a duty to provide those necessities. As such, the military government enacted a patent law of low enforcement. In other words, the strength of protection conferred to new inventions was low. When analyzed in these terms, it might be concluded that China provides a lower degree of protection for new inventions than does Korea.

One of the most notable characteristics of Chinese IP law is the double layer of protection afforded to new inventions, on both the judicial and administrative level. If a firm suffers infringement, it has two options- to pursue either a judicial or an administrative claim against the infringement.

If the firm that has suffered the violation chooses to go the administrative route, there are advantages in terms of reduction of cost, time, and processing of the investigation. However, there are

\begin{tabular}{|c|c|c|c|c|c|c|c|}
\hline & \multirow[b]{2}{*}{ Unit } & \multicolumn{3}{|c|}{ Korea } & \multicolumn{3}{|c|}{ China } \\
\hline & & Volume & Ranking & Global portion & Volume & Ranking & Global Portion \\
\hline Nominal GDP & \multirow{4}{*}{$\begin{array}{l}100 \text { million } \\
\text { Dollar }\end{array}$} & 13,930 & 11 & $1.9 \%$ & $113,847.6$ & 2 & $15.6 \%$ \\
\hline Trade Volume & & $10,961.7$ & 7 & $3.2 \%$ & $43,003.6$ & 1 & 12.5 \\
\hline Import & & $5,719.7$ & 5 & $3.4 \%$ & $23,423.4$ & 1 & 13.8 \\
\hline Export & & $5,242.0$ & 8 & $3.0 \%$ & $19,580,2$ & 2 & 11.3 \\
\hline
\end{tabular}

Table 1: Economic volume of two countries in 2015.

\begin{tabular}{|c|c|c|c|c|c|}
\hline \multirow[t]{2}{*}{ Item } & \multirow[t]{2}{*}{ Definition and Unit } & \multicolumn{2}{|c|}{ Korea } & \multicolumn{2}{|c|}{ China } \\
\hline & & 2013 & 2014 & 2013 & 2014 \\
\hline Total expenditure on R\&D (\$) & US\$ millions & 7 & 6 & 3 & 3 \\
\hline Total expenditure on R\&D (\%) & Percentage of GDP & 3 & 1 & 22 & 46 \\
\hline Total expenditure on R\&D per capita (\$) & US \$ per capita & 20 & 16 & 43 & 39 \\
\hline Patent applications per capita & Number of applications filed per 100,000 inhabitants & 3 & 4 & 24 & 25 \\
\hline Scientific articles & Scientific articles published by origin of author & 9 & 9 & 2 & 2 \\
\hline Intellectual property rights & Intellectual property rights are adequately enforced & 40 & 42 & 51 & 52 \\
\hline
\end{tabular}

Table 2: The comparison of scientific infrastructure of the two countries. 
also disadvantages due to the fact that administrators are not likely to be qualified or possess expert knowledge regarding technological issues. Also, because an administrator does not have the power of enforcement, the firm which has suffered the violation needs to take their claim for infringement to back to the patent court if the infringer has not complied with the instructions of the administrators. However, the disadvantage of taking the judicial route is that it takes a long time to solve the conflict, and large financial costs are also incurred.

Looking at previous studies into the strength of protection for patents, two dominant opinions can be identified. Firstly, Aghion and Howitt, and Grossman and Helpman claim that providing strong protection power for patents by enacting the patent Act encourages a firm or an individual to increase their level of investment in the invention of new technology, in terms of their input into the innovation process $[9,11]$. Teece remarks that the degree of protection for patents has tended to have a positive influence on corporate profit whilst Arora et al note that protection power for patents does not have a positive influence on innovation activities, except for pharmaceutical and special chemical sectors, in the case of the US and EU $[15,16]$. A notable gap exists in patent protection levels, which are weak in largely developing countries [17]. Also, Sakakibara and Branstetter show, through an empirical study, that Japan's case protection power for patents did have a positive correlation with the rate of innovation. They also asserted that the degree of protection power afforded by a patent is likely to vary according to a country's circumstances and the characteristics of industrial sectors [18]. In the scientific infrastructure rankings, Korea received higher scores in its ratio of $\mathrm{R} \& \mathrm{D}$ investment to GDP, the number of patents obtained per total applications and the total workforce involved in the R\&D sectors. In terms of patent applications per capita, Korea's rank is higher than that of China.

However, it is another story with regard to the absolute number of patent applications of China. The current paper utilizes Chinese domestic data to investigate this. The capability of basic scientific research may be the way to narrow the technology gap between the two countries. China holds the second highest rank out of 61 countries for the number of scientific articles published by an original author. This is, in fact, a far more significant statistic. China's current innovation policy aims to establish and nurture an institutional arrangement that facilitates progress in science and technology and innovation, following after Korea; thus, science and technology, and accordingly, science and technology policies form the backbone of its innovation policies. In order to boost R\&D activities, China increased its policy support from 24 in period 1985-1994 to 84 in period 1995-2005 [19]. In this way, China's central government has sought to provide incentives for R\&D (Table 3).
Adapted from National Bureau of Statistics of China (2009, 2012, and 2014)

Table 3 presents China's data pertaining to basic science and technology activities over a three year period. The most notable statistic is the number of patent applications, and the total expenditure on acquisition of foreign technology. In the case of the number of patent applications, in the period from 2009-2014, not only the absolute number of patent applications but also the growth ratio exhibited an exponentially high rate of growth compared to those of Korea $(210,292$ in 2013). Innovations protected by patents play a key role in securing technological competence at the national level as well as at the business level, in that technological improvement have the power to furnish both individual companies and the entire nation with a competitive advantage. Since firms or nations have the ability to make a strategic decision to become either $\mathrm{R} \& \mathrm{D}$ leaders or followers, this implies that China has the potential to become a technologically advanced country.

More importantly, the number of patents per capita could be used as an indicator of the degree of knowledge spillover [20]. Pakes and Schankerman note that knowledge spillovers to other firms occur gradually, but in a dynamic manner [21]. Aghion et al claim that a climate where competition discourages firms that are lagging behind, whilst encouraging those engaged "neck-and-neck" with their competitors, is one that is more conducive to the fostering of innovation [22]. The sustained nature of this influence can have an effect on other firms due to the effect of the competition on the equilibrium of the industry structure. They show that there is an inverted U-shaped relationship between innovation and completion. They claim, in addition, that the average technological distance between innovation leaders and followers increases with competition, and that the inverted- $U$ is steeper when industries are more "neck-and-neck", which is itself a consequence of the knowledge spillover effect.

From the data, it can be surmised that, due to knowledge spillover effects, China has the potential to become a country leading in innovation. Another noteworthy consideration from Table 3 is that China has been trying to buy foreign technology. To secure this, China has been spending vast amounts of money. Figure 3 shows a graphical representation of current trends in the scientific infrastructure of China (Figure 3).

The world bank' data from the period 2010-2014 with regard to patent applications in both Korea and China, bears impressive numerical witness to China's renewed interest in patent propensity. In terms of the growth rate in patent applications, China was almost on the same level as Japan in 2010. However, since 2010, the growth rate of China has been rapidly increasing. This might be an indicator that

\begin{tabular}{|c|c|c|c|}
\hline Item & 2009 & 2012 & 2013 \\
\hline Expenditure on $\mathrm{R} \& \mathrm{D}(100$ million yuan) & $3,775.7$ & $7,200.6$ & $8,318.4$ \\
\hline R\&D Projects(item) & 194,400 & 287,524 & 322,567 \\
\hline Number of R\&D Institutions(unit) & 29,879 & 45,937 & 51,625 \\
\hline R\&D Personnel(10,000 persons) & 155.0 & 226.8 & 238.8 \\
\hline Expenditure on $\mathrm{R} \& \mathrm{D}(100$ million yuan) & $2,983.6$ & $5,233.4$ & $5,941.5$ \\
\hline Number of Patent Applications(piece) & 265,808 & 489,945 & 560,918 \\
\hline Inventions & 92,450 & 176,167 & 205,146 \\
\hline Number of Inventions in Force(piece) & 118,245 & 277,196 & 335,401 \\
\hline Expenditure for Acquisition of Foreign Technology (100 million yuan) & 422.2 & 393.9 & 393.9 \\
\hline Expenditure for Assimilation of Technology (100 million yuan) & 182.0 & 156.8 & 150.6 \\
\hline Expenditure for Purchase of Domestic Technology (100 million yuan) & 203.4 & 201.7 & 214.4 \\
\hline Expenditure for Technical Renovation (100 million yuan) & $4,344.7$ & $4,161.8$ & $4,072.1$ \\
\hline
\end{tabular}

Table 3: Basic statistics on science and technology activities. 
Citation: Han J, Lee W (2016) Patenting Activity - A Proxy of the Technology Gap? The Case of Korea and China. Intel Prop Rights. 4: 151. doi:10.4172/2375-4516.1000151

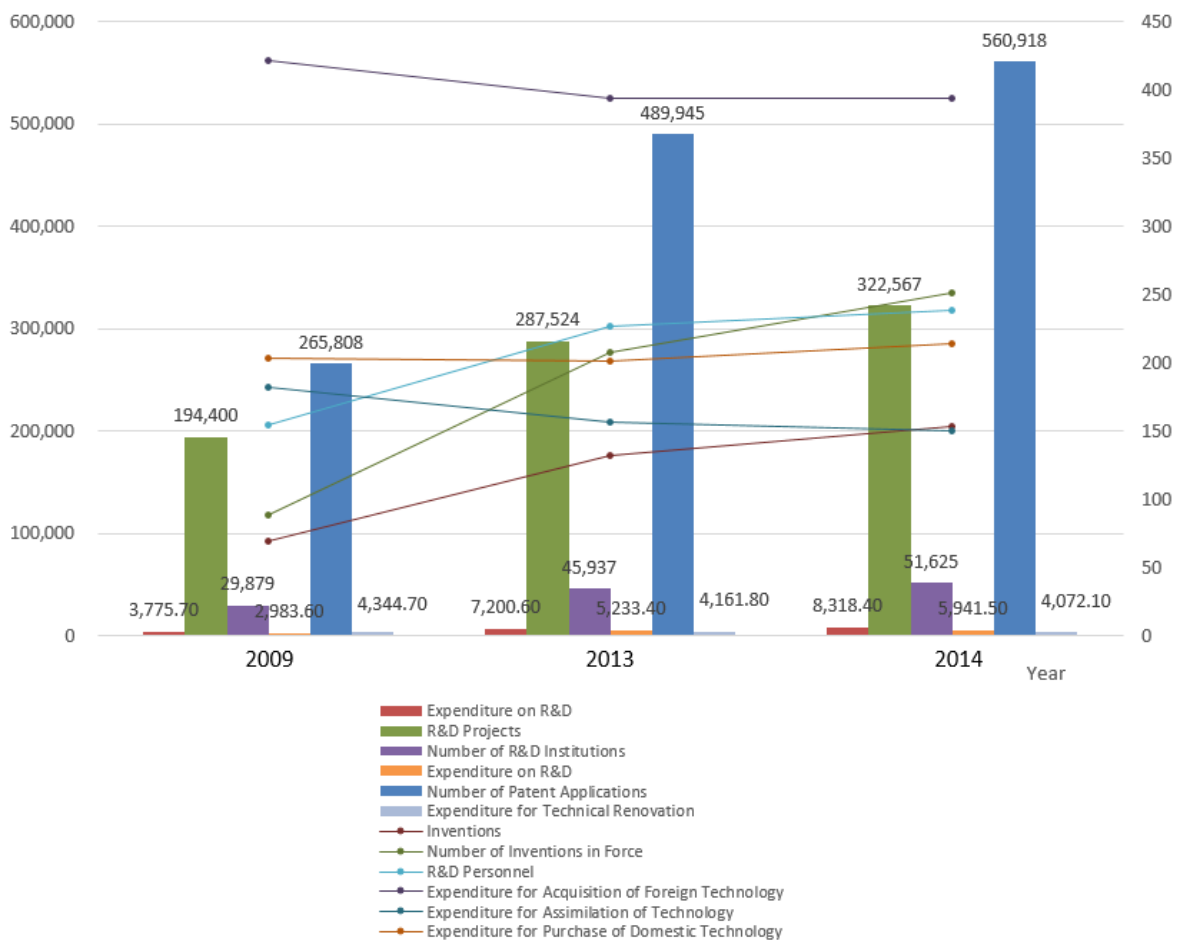

Figure 3: Trends pertaining to the scientific infrastructure in China.

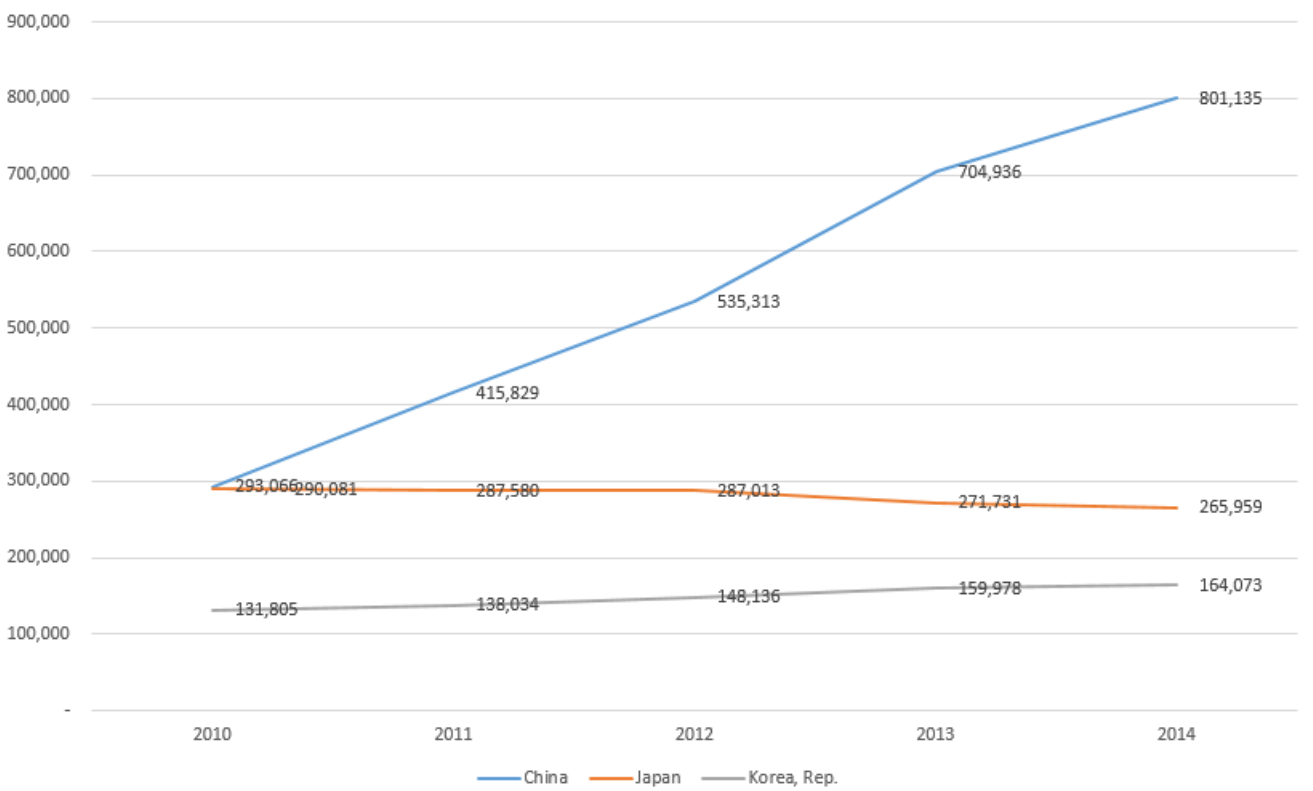

Figure 4: A comparison of patent applications in three countries (Korea, China and Japan) between the period 2010-2014. Adapted from data from the World Bank (2015).

China will become an advanced country in the future. This phenomenon might also be expected to occur by virtue of the protection afforded to new technology by China's Intellectual Property Act (Figure 4).

Figure 4 gives interesting information about the current strength of enforcement of proprietary rights, including patents. Significantly, China has the lowest level of charges relating to payments and receipts for the authorized use of proprietary rights (i.e., patents, trademarks, copyrights, industrial processes and designs including trade secrets, and franchises). In spite of sharp increases in the number of patent applications, inventions, and developments in the scientific infrastructure, enforcement of IP rights is relatively weak.

It is assumed that in the evolving economy, imitation goods do well in China, unlike Korea. In the evolving economy, innovation and imitation formed one of the key areas of discussion in innovation 
Citation: Han J, Lee W (2016) Patenting Activity - A Proxy of the Technology Gap? The Case of Korea and China. Intel Prop Rights. 4: 151. doi:10.4172/2375-4516.1000151

Page 7 of 8

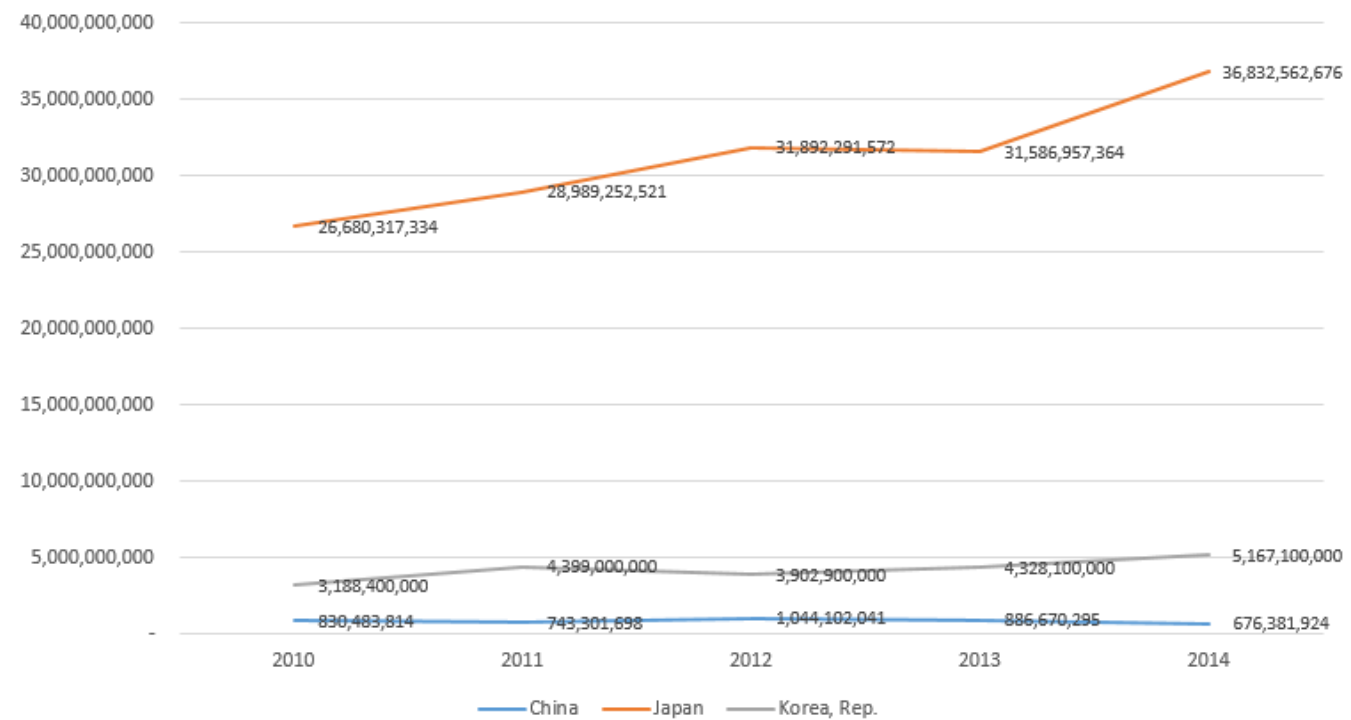

Figure 5: Payments and Receipts for the authorized use of proprietary rights from the period 2010-2014.Adapted from World Bank and IMD (2015) data.

studies. Innovations start where entrepreneurs take existing inventions and transform them into marketable products and productions. Therefore, innovation is understood as the creation of product and its launch on the market, not as the creation or discovery of something virtually new [23]. Beckback's definition of innovation, invention and diffusion was closer to what we understand by innovation [24]. According to his work, 'invention' is the actual discovery of something new, and innovation is its transformation into something marketable, with the diffusion process accounting for whether or how an innovation is actually taken up by customers. 'Imitation' means that firms or individuals copy products of these innovative firms. However, a product is called 'new' for an individual firm if it has not been produced before by this particular firm, regardless of whether it was self-developed or copied.

It is clear that technology is a key determinant of economic growth. However, endogenous growth theory does not explicitly distinguish between innovation and imitation, or discuss the extent to which one is based on the other, or a more profitable alternative. According to Romer, technology progresses regardless of both innovation and imitation, and has an important effect on the local knowledge spillover effect [6]. In this way, knowledge stocks which could be used as the basis for innovation activities increase overtime. Learning through imitation may enable firms to improve existing technologies. Almost all developing countries, such as Korea and Taiwan, have achieved economic growth by a 'catching-up' strategy. Imitation is a more effective method of overcoming the knowledge gap due to the everincreasing size of the pool of potential imitations, and the everdecreasing size of the knowledge gap, which closes with each successive imitation.

Korea has a strong level of patent protection, while China is one of the biggest imitative goods markets in the world due to its weak levels of patent protection. This is important in that it may positively affect the growth of the economy as well as the capability for innovation (Figure 5).

Figure 5 also provides an indication of the technology level in each of the three countries (Korea, China and Japan). The technology gap between Korea and China is narrow, whilst the technology level of Japan far surpasses that of Korea, as well as that of China. Of course, in spite of the fact that Figure 3 does not offer any information about of the specific kinds of technology sectors operating in each country, it does provide a representation of the overall technology gaps between the countries. This can be assumed to be the case because the greater the total knowledge stocks of a country, the higher the likelihood that that innovation and invention will thrive in that country.

So far, this paper has mainly focused on discussing the history of patent law, and various numerical data relating to patent and patenting activities, as well as the publication rate of international scientific research articles in the two countries. It might be premature to conclude that the technology gap between the two countries has narrowed rapidly without an in-depth analysis of both sets of data. In fact, this paper has many limitations. For instance, in order to measure the technology that has been converted into marketable products, total GDP was used; in addition to that, the total factor productivity should also be considered.

Finally, another key insight of this discussion has been that if an innovation is protected by strong intellectual property rights, or if the technology which underlies it is hard for competitors to imitate or emulate, then there is less risk that competitors, and not the original innovator, will profit from it.

\section{Final Remarks}

Patenting and patent propensity activity is an offshoot of the process of technology spillover and diffusion. The technology gap exists because technology diffusion and knowledge spillover is imperfect, which is due as much to the characteristics of technology itself as to those of the social institutions which regulate its development. As a neighbor country, China's technological activities, and in particular its patents and published articles, have attracted attention. In turn, the rapid increase in China of international patenting activities provides Korea with strong impetus to maintain its ongoing technological predominance. 
Citation: Han J, Lee W (2016) Patenting Activity - A Proxy of the Technology Gap? The Case of Korea and China. Intel Prop Rights. 4: 151. doi:10.4172/2375-4516.1000151

As Fagers pointed out, the technology gap will exist as long as all countries do not share the same pool of knowledge [4]. If all countries share all knowledge and technology, it is impossible to measure the level of the technology gap exactly because of the inherent characteristics of technology. With reference to data collected from IMD, World Bank, National Bureau of Statistics of China and Korea, and World Intellectual property Organization (WIPO), this article has explored the extent to which patents or patenting may act as predictors of the technology gap, where the term 'patenting' also includes published articles offering patentable ideas.

Of course, even though the number of patents and articles may not forecast exactly the level of technological competitiveness for some countries, we can at least anticipate that the number will reflect the likelihood that new technology will be created, based on the capacity of the country's scientific infrastructure. Above all, the knowledge spillover effect, combined with the Patent Acts operating within a country, may be important determiners of that country's technological progress.

Both Korea and China have been trying to transition from 'catchingup countries' to 'first movers'. From the data analysis, we found that the absolute volume of investments into the scientific infrastructure in China is tending to becoming increasingly rapidly compared to that of Korea. As such, it can safely be assumed that the technology gap will widen over time, not to mention the possibility that China will in fact overtake Korea. In terms of relative indicators, Korea ranks highly compared to China, but it is likely that the current gap will narrow over time. In short, Korea is being chased by China's innovation activities.

China is weaker than Korea in terms of the strength of its patent protection levels. Considering that weak patent rights are likely to inhibit patenting and may in fact form a barrier to the diffusion of technology, China has a great need to protect its intellectual property (IP). Even though a weak level of patent protection policy may, in the short term, contribute towards the overall knowledge spillover to some degree, in the long run, this may in fact hinder the process of knowledge diffusion [17].

This paper suffers from several limitations, including the fact that only descriptive statistics were employed without the use of regression, as well as the short period encompassed by the study. In spite of these limitations, however, it is hoped that the macro approach taken in this comparison of the technology gap between Korea and China will be of use to policy makers and lawmakers, as well as to scholars who are interested in technology and patenting activity.

\section{References}

1. Cohen WM, Nelson RR, Walsh JP (2000) Protecting their intellectual Assets: Approrpriability conditions and why firms patent or not? NBER 75: 52.

2. Gerschernkron A (1962) Economic backwardness in historical perspective historical. Harvard University Press p: 456.

3. Abramovitz M (1986) Catching-up forging ahead and falling behind. Journal of economics history 46 : 385-406.

4. Fagerberg $\mathrm{J}$ (1994) Technology and International differences in growth rates. Journal of Economic Literature 32: 1147-1175.
5. Fagerberg J, Verspagen B (2002) Technology-gaps innovation-diffusion and transformation: an evolutionary interpretation. Research policy 31(4): 1291-1304.

6. Romer PM (1990) Endogenous technological Change. Journal of Political Economy 98: 71-102.

7. Verspagen B (1991) A new empirical approach to catching up or falling behind Structural change and economic dynamics 2(2): 359-380.

8. Castellacci F (2001) A Technology-gap approach to cumulative growth: Toward and Integrated Model DRUID 01-04.

9. Aghion P, Howitt (1998) Endogenous Growth Theory Cambridge MA: The MIT Press.

10. Silvergerg G, Verspagen B (1995) Long term cyclical variations of catching up and falling behind; An evolutionary Model. Journal of Evolutionary Economics pp: 209-227.

11. Grosman GM, Helpman E (1991) Innovation and Growth in the Global Economy. Cambridge MA: The MIT Press.

12. Blazsek S, Escribano (2016) A Patent propensity R\&D and Market competition Dynamics spillovers of innovation leaders and followers 191: 145-163.

13. National Bureau of Statistics of China. International Data

14. IMD world competiveness year book.

15. Teece DJ (1986) Profiting from Technological Innovation: Implications for Integration Collaboration Licensing and Public Policy. Research Policy 15: 285-305.

16. Arora A, Ceccagnoli M, Cohen WM (2003) R\&D and the Patent Premium Working Paper 9431 National Bureau of Economic Research Cambridge M.A.

17. Park WG (2013) International patenting patent rights and Technology Gaps. Review of Economics and Institutions 4(1): 1-25.

18. Sakakibara M, Branstetter L (2001) Do Stronger Patents Introduce More Innovation? Evidence for the 1988 Japanese Patent Law Reforms. Rand Journal of Economics 32: 77-100.

19. Liu F, Simon DF, CongCao Y (2011) China's innovation polices: Evolution institutional structure and trajectory. Research Policy 40: 917-931.

20. Jaffe AB (1986) Technological opportunity and spillovers of R\&D: Evidence from firm's patents Profits and market value. America Economy Revolution 76(3): 984-1001.

21. Pakes A, Schankerman M (1984) The rate of obsolescence of patent research gestation lags and the private rate of return to research resources. In: Griliches Z (ed.) R\&D Patent and Productivity 1984 University of Chicago Press. Chicago.

22. Aghion P, Bloom N, Blundell R, Griffith R, Howitt P (2005) Competition and innovation: An inverted-U relationship. The Qurterly Journal of Economy 120 701-728.

23. Nelson RR, Winter SG (1982) An evolutionary theory of economic change. Cambridge: Harvard University Press.

24. Beckenbach F (2005) Knowledge Representation and Search Processes: A contribution to the Microeconomics of Invention and Innovation. Universität Kassel: Volkswirtschaftliche Diskussionsbeiträge. 